\title{
HABER TOPLAYAN VE SATAN KURULUŞLAR : HABER AJANSLARI
}

\author{
Dr. Oya TOKGöz \\ Gazetecilik Asistanı
}

\section{Genel Olarak Haber Ajansları}

Günümüz gazeteciliğinin haber alma kaynağının belkemiğini teşkil eden haber ajanslarının bașlangıcı 1835'te Macar asıllı bir Fransız olan Charles Havas'ın kurduğu Havas haber ajansıdır. Havas,, ajansını kurduğu zaman gazeteler haberlerini satın almaktan çekinmişler, buna karșılık diplomatlar, bankerler verdiği haberlere abone olmuşlardır.' Havas ajansını, Almanya'da 1855 yılında Wolff, ${ }^{2} 1857$ 'de İngiltere'de Reuter, ${ }^{3}$ haber ajansları izlemişlerdir. XX. yüzyılın bașında kurulan Associated Press (1900), United Press (1907), ve International News Service (1909) Avrupa'daki yeni gazetecilik akımını A.B.D'de gerçekleştirmek amacını gütmüşlerdir.4 Haber ajanslarının gelișmesi ve sayılarının artması, özellikle, II. Dünya Savașından sonra hızlanmıştır. Bugün için dünyadaki sayılarını belirtebilmek güç bir işlem haline gelmiștir. ${ }^{5}$

Haber ajansları genellikle, basın endüstrisinde ayrı bir bölüm meydana getirdikleri gibi, kuruluşları, işleyișleri bulundukları ülkelerin hukuki rejimlerine göre değişmektedir. 1835 yılında ilk kez ortaya çıktıklarından beri, haber ajanslarının amacı başka haber veren kuruluşlara haber bulma ve yayma görevini yapma olmuştur ve olmaktadır. Bu bakımdan, haber ajansları tarifi gereği olarak, "kitle haberleşme araçlarına ortak hizmet götürme işle-

(1) Les Agences Télégraphiques L'information, Unesco, Paris, 1953, s. 13. Francis Williams, La Transimission de l'Information, Unesco, Paris 1953 - s. 21.

(2) Les Agences Télégraphiques D'information, op. cit., s. 13.

(3) ibid., s. 14.

(4) ibid., s. 14-15.

(5) L'Information A Travers Le Monde, Unesco, Paris, 1966, s. 15. 
mini yerine getirmektedirler».6 Yalnız, haber ajansının gerçekten tarifini yapmak güç bir iştir. Çeșitli ülkelerin kanûnlarında verilmiş bulunan tarifler, daha çok kendilerine özgü özellikler taşımaktadırlar.

Bir tarife göre, haber ajansı, "gazete, radyo, televizyon, dergiler gibi kitle haberleşme araçlarına ulusal, uluslararası ve yerel kaynakl haber temin eden bir kuruluştur».7 Bunun yanında, haber ajansları, kitle haberleşme araçlarına, fotoğraf, eleştri, karikatür, resimli roman ve ropörtaj gibi haberlerin tamamlayıcı ürünlerinin de temininde görev almaktadırlar. UNESCO, haber ajansinın tarifinin güçlükleri karşısında aşağıdaki gibi bir tarifin kullanılmasını ön görmektedir : ${ }^{8}$

"Haber ajansı, hukuki statüsü ne olursa olsun, genel anlamda, haberleri, gerçekleri gösteren ve tanımlayan aktüalite belgelerini bulup, bunları kitle haberleşme araçlarına onları ikna etmenin dışında kalmak üzere yayan, kanûnların hükümlerine ve ticaret kurallarına uygun, mümkün olduğu ölçüde tam ve tarafsız bir hizmettir.»

Haber ajansları yukarıda verilen tariflere bakılınca, haber alma toplama ve yayma ișiyle görevli muhabirlerin ișlerini daha geniş anlamda yapan kuruluşlar olarak göze çarpmaktadırlar. Ellerinde bulunan teknik olanaklarla, haber alma ve yayma işlemini daha çabuklaştırdıkları gibi, aynı nitelikte görev yapan kitle haberleșme araçlarına oranla daha ucuza da mal edebilmektedirler. $\mathrm{Bu}$ bakımdan, haber ajanslarını çağımızın «anonim muhabirleri» olarak nitelemek yalnış bir görüş olmamaktadır.

Yalnız, bu gelişime rağmen, gazeteciliğin demirbaş elemanları olan muhabirler ortadan kalkmıș değildir. Kitle haberleşmesi alanında, yine de muhabirlik kurumu vardır, devam edecektir de... $\mathrm{Bu}$ bakımdan, haber ajanslarını, muhabirlik kurumunu ortadan kaldıramamakla beraber, muhabirlik hizmetine kolaylıklar getiren, hattâ muhabirliğe yeni boyutlar kazandıran kuruluşlar olarak nitelemek daha doğru bir görüş olmaktadır.

$\mathrm{XX}$. yüzyılın ikinci çeyreğinde radyonun ilerlemesi, telefon, teleks, telefoto hizmetlerinin gelişmesi, televizyonun büyük süratle

(6) Les Agences Télégraphiques D'information, op. cit., s. 26.

(7) John Hohenberg, Gazetecilik Mesleği (The Professional Journalist), (çeviren: Filiz Ofluoğlu), Istanbul: İstanbul Gazeteciler Cemiyeti Yayınları NO : 1, 1963 , s. 147.

(8) Les Agences Télégraphiques D'information, op. cit., s. 27. 
dünyaya yayılması, uzaya fırlatılan haberleşme uydularının haber alışveriși sürecine yeni ve değişik katkıları ile bugünkü gazetecilik nitelik ve şekil bakımından eskisinden farklı olma durumuna girmiştir. Daha başka bir deyișle, teknik ilerlemeler, gazeteciliğe kolaylıklar sağlarken, gazeteciliği de külfetlere sokmuş ve sokmaktadır. Gazetecilik, teknik ilerlemeler karşısında çabuk, kolay haber alma ve verebilme olanaklarına kavuşmus fakat bunların giderleri yüzünden ise yeni finansman kaynakları aramak ve bulmak durumunda kalmıș ve kalmaktadır.

Bugünkü modern uygarlık, süratli haber alıșverișiyle insanoğlunu tatmin bakımından gazetecilikte, ellerinde teknik ileri olanakları bulunduranları veya bunları bulunduranları kullananları bașarılı hale getirmiş durumdadır. Teknik alandaki ilerlemelerle haber hizmetlerinin maliyet fiyatlarının artması karşısında, kitle haberleșme araçları bakımından haberleri daha iyi verebilmek hem de artan haber maliyetini karşılayabilmek için, haber alma kaynaklarını gözden geçirmek durumuyla karşılaşmıșlardır. Zira, gerek sözlü gerekse yazılı basının temeli haberdir. Haber ise çabuk bayatlayan, hemen değerini yitiren bir metadır. Haber, taze ve doğru olduğu ölçüde insanoğlunun ilgisini çekebilmektedir. Bu bakımdan haberlerin, çabuk, taze, doğru olarak verilmesi için büyük masrafların yapılması zorunlu olmaktadır. Isște, yazılı ve sözlü basın muhabirlerini elden çıkarmamakla beraber, belirli ücret karşılığında haber satan kurulușlar olan haber ajanslarından haber temini yolunu tutmuşlardır.

Haber ajansları aslında geleneksel anlamda, muhabirlerin yapmakla görevli oldukları haber toplama ve yazma işicmlerini yapmaktadırlar. Yalnız, bunları bütün kitle haberleşme araçları için haber haline getirmekte, herkesin kullanması için belirli bir ücret karşılığında satmaktadırlar. Daha doğrusu, haber ajansının yap. tığı hizmetler, ticaret sahasında bir mal toptancısının hizmetine çok benzemektedir. Mal toptancısı nasıl malını belirli bir kârı kendisine ayırdıktan sonra, ikinci el olarak nitelendirebileceğimiz kişilere satarsa, haber ajansları da hazırladıkları haber bültenlerini ve haberlerin yan ürünlerini, müşterisi olan kitle haberleşme araçlarına satmaktadırlar. Haber ajansının hazırladıklarını kullanan diğer kitle haberleşme araçlarını ise, "haber perakendicisi» olarak nitelemek, bu bakımdan pek yanlış olmamaktadır.?

(9) Hohenberg, op. cit., s. 147. 
Haber ajansının müșterisi durumunda bulunan kitle haberleşme araçları, her zaman haber ajansının verdiklerini kullanıp kullanmamakta serbesttirler. Yalnız, haber ajanslarının verdikleri ile yetinmeyip, muhabirlik kurumuna da yer vermeyi ihmal etmemektedirler. Daha doğrusu, kendi kaynakları ile haber ajanslarının verdiklerini ellerinden geldiği ölçüde kanıtlamayı uygun görmektedirler. Bu psikolojik özelliği ister "şüphecilik» isterse "denetim veya süzme» olarak adlandıralım ve nitelendirelim, kitle haberleşme araçlarında var olan bu durum, haber ajanslarının yaşamasına, ilerlemesine ve gelişmesine hiçbir zaman engel olacak bir duruma gelememektedir.

\section{Haber Maliyetinin Artması ve Haber Ajansları}

Kitle haberleşme araçlarının haber hizmetleri için harcadikları paralar günümüzün modern, karmaşık düzeni dolayısıyla çok yüksek düzeye ulaşmış bulunmaktadır. Bu durum giderek te da ha da artma gösterecektir. $\mathrm{Bu}$ bakımdan, kitle haberleşme araçları, kendi haber alma kaynaklarını genişletmektense, daha çok «az ve öz» örneğini seçmeyi uygun görme yoluna gideceklerdir.

Insan gücüne ödenen ücret yanında, modern dünyamızın ayrılmaz parçaları olan telefon, teleks gibi ulaşım giderleri, ve diğer giderler bu durumu ister istemez gerektirmektedir. İște, ekonomik bakımdan karşılaşılan güçlükler, zorunlu olarak haber ajanslarının hizmetlerini kullanmayı gerektirmektedir görüșünü akla getirmektedir. Yalnız, bütün kitle haberleșme araçları bunu uygun bulmakta mıdırlar? Yoksa, hâlâ alıșılagelmiș muhabirlik hizmetini mi kullanmaktadırlar? Bu soruları cevaplayabilmek gerçekten güçtür. Zira, bunun doğru cevabını bulmak, kitle haberleşme araçlarında çalışanların olduğuna bakılınca, güç gibi görünmektedir. Bir de, kitle haberleşme araçlarının muhabir çalıștırdıkları halde haber ajanslarının hizmetlerinden faydalandıkları göz önüne alı. nınca, işin kolaylıkla içinden pek çıkılmayacak gibi güç olduğu gerçeğini ortaya çıkarmaktadır.

Kitle haberleşme araçlarının haber ajanslarını hem eleştirmeleri hem de kullanmaktan vazgeçmemeleri bir yana, muhabirlik kurumunu da ortadan kaldırmamaları, ikisinden de ayrılamadiklarını göstermektedir Yalnız, haber ajansları, bütün bunlara rağmen, neden hâlâ kitle haberleşme araçlarına hizmet götürmektedir sorusu karşısında, haber ajanslarının kendilerini basit bir tüccardan pek farklı olarak görmedikleri durumuna bizi götürmektedir. 
Zira, haber ajanslarını hem kitle haberleșme araçları eleștirmektedirler, ${ }^{10}$ hem de bunların verdiklerini icabında kendi haber alma kaynaklarıyla elde ettiklerini ileri sürmektedirler.

Kitle haberleşme araçlarının haber alma ve verme görevini yaparken haber ajanslarına karşı takındıkları yukarıda anlatılan tutum, bunları çalıștıran ve kullanan insanların bencil karakterinin bariz bir göstergesinden başka bir şey değildir. "Bunu ben yaptım» diyebilmek bakımından, haber ajansının verdiklerini kendisininmiş gibi göstermeyi dahi uygun saymaktadır. Aslında, emek, haber ajansının anonim hizmet gören muhabirlerinindir.

Öbür yanda, haber ajansının verdiklerini kendileri yazmış gibi kullananlar, hiçbir zaman bunu düşünmeden hareket etmektedirler. Para karşılığında aldıklarını, emek sarfetmeden elde ettiklerini ise, belki ufak tefek düzeltmeden ve eklerden sonra kamu cyuna, kendi haber alma kaynağı olarak sunmayı olağan olarak kabul etmektedirler. Burada, diğer bir gazetecilik işlemi işin işine karışmaktadır Redaksiyon (yeniden kaleme alma) olarak adlandırılan bu işlem, günümüz gazeteciliğinin olağan bir ișlemi ve değișmez bir niteliği olmuştur demek hiç te yalnış olmamaktadır.

Yukarıda değinildiği gibi, haber alma ve toplama hizmetlerinin çok pahalanması yüzünden, kitle haberleşme araçlarının haber verme görevinde, büyük ölçüde haber ajanslarından. yararlanmaları, haberin özüne ve ruhuna yani orijinal olma niteliğine dokunmadan bazı düzeltmeler ve ekler katma işlemi olan redaksiyonun kullanılmasını zorunlu hale getirmektedir. Daha doğrusu, bugünkü gazetecilik, haber ajanslarından aldıklarını "kendi haber kaynaklarımdan sağladım» diyebilmek bakımından redaksiyon işlemine dört elle sarılmaktadır. Redaksiyon, böylelikle, haber ajansları kadar bugünün gazeteciliğinin temel etkenlerinden bir tanesi olmaktadir.

Haber ajansları, kitle haberleşme araçlarının haber alma kaynaklarının belkemiğini teşkil etmekte, redaksiyon ise haber hizmetine ödediklerini gizleyebilmek bakımından büyük bir koz olarak kullanılmaktadır. Daha başka bir deyişle, bugünün gazeteciliğinin demirbaş elemanları olan muhabirler iyi birer redaktör olarak hizmet görmektedirler.

Yalnı, haber hizmeti maliyetinin artması, her yerde haber toplama ve alma hizmetinin tamamen haber ajanslarının üstelen-

(10) ibid., s. 154-155. 
mesi ve redaksiyon işlemiyle ,ajanslardan alınanların kitle haberleşme araçlarının kendi haber kaynaklarıyla topladıkları şeklinde gösterilmesi yönünde olmamaktadır. Büyük gazeteler, radyo ve televizyon istasyonları ve șebekeleri, haber ajanslarını kaynak olarak göstererek redaksiyon yoluyla, bunların verdiklerini kullandıkları gibi, büyük giderler pahasına, kendi haber toplama ve alma hizmetlerini de hâlâ yürïitmektedirler. Daha başka bir deyișle, ken. di haber toplama ve alma hizmetleri ile haber ajanslarını karşılaştırarak kullanma yolunu tutmaktadırlar. Örneğin : Ingiltere'de BBC, A.B.D' CBS, NBC ve ABC-, Fransa'da ORTF gibi radyo ve televizyon hizmetleri ile A.B.D'de New York Times, Chicago Sun Times, Fransa'da Le Monde gibi gazeteler bu iki hizmeti hâlâ birlikte kullanmaktadırlar.

$\mathrm{Bu}$ durum devam edecek midir, yoksa gün haber ajanslarının mı olacaktır sorularının cevaplarını verebilmek bugün için çok güçtür. Hızlı teknik gelişmeler, dünyayı giderek küçültmektedir. $\mathrm{Bu}$ bakımdan, "haber» tazeliğini, çok çabuk kaybetmektedir. Bayat olsun, taze olsun haber hiçbir zaman eskiden olduğu gibi kolaylıkla kapıșılmamaktadır. Haberi haber yapan tazelik, çabukluk ve doğruluk unsurları haber ne kadar süratli verilebilirse, önemli slabilmektedir.

Sürat, küçülen dünyamızı birbirine hem yaklaştırmakta hem de uzaklaștırmaktådır. Daha doğrusu, haber ne kadar süratli olarak ulaşabilirse, tazeliğin koruyabildiği gibi, dünya kamu oyunu - kađar çabuk aydınlatmakta, oluşturmakta ve şekillendirip biçimlendirmektedir. Bu bakımdan, haber verme görevi kitle haberıeșme araçlarının çağımızın sürat anlayışı ve düşünüşü ile atbaşı gitmektedir demek yalnış olmamaktadır. Hattâ burada atbaşı deyimini kullanmak bile uygun düșmemektedir. Zira, sürat anlayıșı bakımından, «ıșık veya ses hızı» kavramlarını kullanmak belki daha uygun görünmektedir.

\section{Dünya Haber Alıșverișini Yürütün Haber Ajanslarından Örnekler}

Daha öncede dokunulduğu gibi, haber ajansları ulusal, uluslararası haberlerin dağıtılıp yayılması bakımından temel araç veya kanal hizmetini gören kuruluşlardır. Yazılı ve sözlü basın, daha çok, yerel haberlerini kendisi toplayıp yazma görevini kolaylıkla yapabilmektedir. Buna karşılık, ulusal ve uluslararası haberleri için haber ajanslarına başvurmaktadır. 
II. Dünya Savașızdan sonra, dünya haber ajanslarının sayısında artıș görülmüştür. Bu sayı giderek te artmaktadır. 1950'den sonraki teknolojik gelișmeler, mevcut haber ajanslarının kendilerine daha çok çeki düzen vermelerine yol açmıştır. Geleneksel telgraf hizmeti, telefon, teleks, kiralanmıș radyo hatları, çok yönlï radyo haberleşmesi ile yenilenmiştir. 19 Haziran 1962'de ise haber ajansları da uzay çağına girmişlerdir. Böylelikle, kıtalar arasındaki telefon ve telekslerin faaliyetleri yanında haberleşme uyduları da çalışmağa başlamıştır. Bugünkü dünya haber alışve. rişini hızlandırıp, çeviren haber ajanslarının nasıl çalıştıkları ve örgütlendikleri hakkında bir fikir sahibi olabilmek bakımından dünyadaki mevcut beş büyük haber ajansına göz atmada fayda bulunmaktadir.

Dünya haber alışverişinde ilk akla gelen beş büyük haber ajansı sirasiyla A.B.D'deki Associated Press (A.P), ve United Press

International (UPI), Fransa'daki Agence France Presse (A.F.P), Ingiltere'deki Reuters, S.S.C.B'deki Tass'tır.

\subsection{Amerikan Haber Ajanslari}

\section{A) Associated Press ${ }^{11}$}

1900 yilında kurulan Associated Press, dünyada mevcut en eski haber ajansıdır. Elindeki olanakları kullanarak, hergün üyelerine ve abonelerine -gazete, radyo, televizyon istasyonları, haber ajansları- dünya haber bülteni vermektedir.

Reuters, Tass ve Agence France Presse gibi üç büyük haber ajansı ile yaptığı haber değiş tokuş antlaşmaları gereğince, kendi haberlerini bunların haber sahalarında tamamlamaktdır.

Bütün Amerikan gazetelerinin ortak mülkiyetinde bulunan Associated Press kâr gayesi gütmemektedîr. Associated Press'in A.B. D'de 110 bürosu, 57 tane de yurtdıșı bürosu bulunmaktadır. 2500 tam zamanlı, 1000 den fazla da yarım zamanlı muhabir çalıştırmaktadır. Associated Press, 24 saat boyunca, 80 kadar ülkede 7.582 aboneye hizmet etmektedir. Ayrıca, haber ajansları bakımından yenilikler ve gelișmelerden sorumlu bulunan bir elektronik laboratuvarı da bulunmaktadır. 


\section{B) United Press International ${ }^{12}$}

1958'de United Press ve International News Service'in birleș. mesiyle kurulan United Press International, A.B.D'de 151 büro, 110 tane de diş büro işletmektedir. Haberlerini 48 dil üzerinden, 111 ülke ve bölgeye göndermektedir Devamlı ve yarım zamanlı muhabirlerinin sayısı 10.000 nin üzerindedir.

\subsection{Avrupa Haber Ajansları}

Avrupa iki büyük haber ajansının vatanıdır. Ingiltere'de Reuters Fransa'da Agence France Presse, A.B.D'deki Associated Press ile United Press International ile birlikte dünyadaki dört büyük haber ajansını meydana getirmektedirler.

\section{A) Agence France Presse (AFP) ${ }^{13}$}

Agence France Presse'in Fransa dişında 82 bürosu ile 79 dış muhabiri bulunmaktadır. Reuters, Associated Press, Tass, D.P.A (Federal Almanya Haber Ajansı), NCNA (Çin Halk Cumhuriyeti Haber Ajansı) ile ulusal haberlerini değişmektedir.

39 diş ajans Agence France Presse'in uluslararası haber hizmetlerini satın almakta, buna karşılık, kendisi 20 dünya haber ajansının ulusal haberlerini almaktadır. 104 ülkeye hergün haber dağıttı̆̆ı gibi, Fransız hükümeti Agence France Presse'in baș müşterisidir.

Agence France Presse özerk bir kuruluştur, yönetim kurulundaki sekiz üyesini Fransız basını temsil etmektedir.

\section{B) Reuters ${ }^{14}$}

Reuters kâr gayesi gütmeyen, Birleşik Krallık, Avusturalya ve Yeni Zelanda gazetelerinin sahip olduğu bir kooperatiftir. Reuters hiçbir zaman İngiltere içindeki abonelerine ulusal haber satmamakta, yurtdışına İngiltere'nin iç haber ajansı olan Press Association'in haberlerini satmaktadir.

Reuters'in 60 ülkede bürosu bulunmaktadır. 110 ülkeye ayrı ca haber dağıtmaktadır.
(12) ibid., s. 166.
(13) ibid., s. 319.
(14) ibid., s. $359-360$. 


\subsection{S.S.C.B Haber Ajansı : TASS ${ }^{15}$}

Dünyanın beșinci büyük haber ajansı olan Tass'ın (Telegrafnoie Agenstvo Sovietskavo Soyusa) merkezi Moskova'dadır. S.S.C. B'nin resmi ajansı olan Tass, 15 Sovyet cumhuriyetine dünya haberlerini vermekten ve cumhuriyetler arasında haber göndermekten sorumlu bulunmaktadir.

S.S.C.B içinde 3650 kadar gazete, dergi, radyo ve televizyon istasyonuna haber satan Tass, Kiril alfabesini kolay bir şekilde uygulayan telekslerle haberlerini ulaştırmaktadır. Yurtdıșında, $30 \mathrm{ka-}$ dar haber ajansı ile antlaşma yoluyla haber alışverişi yapmaktadir.

\section{Haber Ajansları ve Hukuki Düzen}

Yukarıda anlatılan beş büyük haber ajansının kurulușlarında görüldüğü gibi, haber ajansları gibi gerek ulusal gerekse uluslararası kitle haberleşmesinde büyük rol oynayan kuruluşların çalıșmasında tıpkı üç büyük kitle haberleşme aracı olan basın, radyo ve televizyon da olduğu gibi siyasal rejimlerin uyguladıkları politikanın rolü oldukça büyüktür. "Zira, kitle haberleşme araçlarının varlıklarının temeli olan haberleşme özgürlüğü, bu araçların bulunduğu ülkenin siyasal yapısı ve düzeyi ile uygulanabilme olanağına kavuşabilmektedir. Kitle haberleşmesinin işleyebilmesi için gerekli olan haberleşme özgürlügüünün kullanılması, o ülkenin siyasal yapısını ortaya çıkarabilmekte ve yansıtmaktadır.» ${ }^{16}$

Haber ajansları üç büyük kitle haberleșme aracından olan basının içinde yer aldıklarından, siyasal rejimler tarafından kitle haberleșmesi ve araçları üzerinde uygulanan politika gereği olarak, kurulup çalışabilmektedirler. Siyasal rejimlerin kitle haberleşmesi bakımından uyguladıkları politika, genellikle, bunların ișlemesine hiç karıșmama veya çeşitli yollara başvurarak işlemelerine karışma şeklinde kendini göstermektedir.

Birinci șekilde, siyasal rejimler, hiç karıșmama politikası ile kitle haberleşmesini serbest, kesin ve tarafsız olarak çalıșma ve işleyebilme olanakları tanımaktadırlar. Daha başka bir deyişle, "siyasal yönetim kitle haberleşmesini, rejiminin temelinde yatan

(15) ibid., s. $409-410$.

(16) Oya Tokgöz, Türkiye ve Ortadoğu Ülkelerinde Radyo ve Televizyon Sistemleri: Mukayeseli Bir Araștırma, (Basılmamış doktora tezi, s.
40-41\}. 
gerçeğin aranıp bulunması için $»,{ }^{17}$ zemin hazırlayacak bir araç olarak görmektedir. Bu șekil bir düzende işleyen kitle haberleşmesi serbest haberleșme olarak nitelenebilmektedir. ${ }^{18}$

İkinci şekilde ise siyasal rejim, resmi felsefesini kitle haberleșmesi yoluyla yaymaktadır. Bu şekil kitle haberleşmesinde, kitleleri yöneltmek ve gütmek amaç olduğundan, haberleşme özgürlüğü ancak güdümlï șekilde bulunmaktadır. Bu bakımdan, siyasal rejimin çeşitli yollarla kitle haberleşmesine karıșmasını ve dïzenlemesini güdümlü haberleșme olarak tanımlamak mümkün olmaktadir. ${ }^{19}$

Yukarıda verilen iki ayrımdan, birincisi Batı demokrasilerindeki, ikincisi ise Marksist rejimlerle, az gelişmiş ülkelerin haberleşme sistemlerini teorik olarak yansıtmaktadır.

İki şekilde de, hukuki bakımdan farklılık, haber dağıtma ve yayma yönünden, birinci şekilde haberler üzerinde tekel durumunun olmaması, buna karşılık ikinci şekilde ise tekelin az veya çok ölçüde mevcut bulunmasıdır. ${ }^{20}$

UNESCO, serbest haberleşme sistemi altında çalışan haber ajanslarını üç gruba ayırmaktadır : ${ }^{21}$

1 - özel, adi, ticari işletme şeklinde çalışanlar

2 - kooperatif şeklinde düzenlenen veya basın ve haberleşme kurulușlarının yönetimi ve denetimi altına konulmuş olanlar

3 - özel statülü işletme olarak çalıștırılanlar.

Güdümlï haberleşmenin mevcut bulunduğu ülkelerde kurulmuş bulunan haber ajansları için, UNESCO, «bunların hukuki statülerinin önemli olmadığı, fakat kuruluşu yönetenlerin dikkate alınmak gerektiği $»^{22}$ üzerinde durmaktadır.

Haber ajanslarının kurulușları ve işleyişleri ülkeden ülkeye göre değişmektedir. Genellikle, ajanslar, basın işletmeleri şeklinde kabul edilmektedirler. ${ }^{23}$ Haber ajanslarında, özellikle muhabir ola-

(17) ibid., s. 44.

(18)( Feyyaz Gölcüklü, Haberleșme Hukuku, Basın, Radyo-Televizyon, (Ankara, Sevinç Matbaası, 1970), s. 9.

(19) ibid., s. 9-10.

(20) Les Agences Télégraphiques D'information, op. cit.. s. 28.

(21) ibid., s. 28.

(22) ibid., s. 33.

(23) ibid., s. 33. 
rak çalışanlar, serbest haberleşme sistemi olan ülkelerde, ajansın hukuki șekli ne olursa olsun, gazetecilere taninan bütün hak ve yetkilerden yararlanmaktadırlar. ${ }^{24}$

Gerek serbest haberleşme gerekse güdümlü haberleşme sistemlerinin bulunduğu ülkelerde, haber ajansları haber toplamak bakımından büyük güçlüklerle karşılaşmamaktadırlar. Asıl önemli olan sorun, uluslararası haberlerin toplanıp dağıtılmasındadır. Serbest haberleşme sistemi bulunan ülkelerdeki haber ajansları bakımından, uluslararası haberler ticari sözleşmeler gereğince dağıtılmaktadır. Uluslararası haberlerin dağıtılması için ödenen ücretler bakımından çeşitli tarifeler kullanılmaktadır. ${ }^{25}$

Haber ajanslarının kendi ülkesi dişında, yurtdışı muhabir bulundurması, bunlar aracılığı ile haber toplayıp dağıtması uluslararası bir sorun yaratmaktadır. Yurtdıșı muhabirin ajansına haberi ulaştırması için ne gibi olanaklar kendisine tanınacaktır veya tanınmayacaktır konusu, yıllardır üzerinde durulan bir sorundur.

Yukarıdaki sorun bir yana, uluslararası haberlerin temini ba kımından uygulanan iki yol bulunmaktadır. Haber ajansları, uluslararası haberleri temin edebilmek ve dağıtabilmek için, karșılıklı değiș tokuş sözleșmeleri veya abone sözleşmeleri imzalamakla bu sorunu biraz hafifletmektedirler.

Değiş tokuş sözleşmelerinde, iki ajans ulusal haberlerini değiștirmektedirler. Abone sözleşmesinde ise, ajans veya ajanslar, diğer bir ajansın yayınladığı bültenlere belirli ücret karşılığında abone olmaktadirlar. ${ }^{26}$ Bütün bunlar bir yana, ajanslar tarafindan verilen haberlerin korunması, daha başka bir deyişle, ajansta çalıșan muhabirin korunması, savunulması sorunu, hukuki bakımdan hâ. lâ bir çözüme kavuşturulmamış durumdadır. ${ }^{27}$

\section{Türkiye'deki Durum}

Türkiye'de de gerek yazılı gerekse sözlü basın büyük ölçüde, haber ajanslarının kendilerine sağladığı büyük kolaylıklardan yararlanmaktadırlar. Daha açık bir deyișle, Türkiye'de haber ajansları verdiklerinin semeresini rahatlıkla alabilmektedirler.

(24) ibid., s. 33 .

(25) ibid., s. 33,34 .

(26) ibid., s. 35.

(27) ibid., s. 35. 
Osmanlı İmparatorluğunun son zamanlarında Havas ve Reuter gibi yabancı özel haber ajanslarının çalışmalarına tanıklık eden Türk toplumu, ${ }^{28}$ haber ajansı kurmanın gerekli olduğunu İstiklâl Savaşını verirken anlamıștır. Atatürk, Ankara'da T.B.M.M. Hüküimetini kurduğu zaman, İstanbul'daki basina faaliyetlerini anlatabilmek için, 6 Nisan 1920'de küçük bir haber bürosu kurmuştur. Küçük bir personel kadrosu ve şapirograf teksir makinesi ile işe başlayan büro, 1 Mart 1925 tarihinde devletin de ortak olduğu bugünkü Anadolu Ajansı șeklini almıștır. ${ }^{29}$

Bugün Anadolu Ajansının yanında iki özel haber ajansı Türki. ye'nin haberleşme sisteminde söz sahibi bulunmaktadır. Bunlardan bir tanesi 1950 yılında Kadri Kayabal tarafından kurulan Türk Haberler Ajansıdır. ${ }^{30}$ Diğeri ise Hürriyet Matbaacılık A.Ș tarafından 1 Mayıs 1963'te gerçekleştirilen Haber Ajansıdır. Anılan üç haber ajansının yanında diğer küçük haber ajansları bulunmaktaysa da, haber alışverişinde fazla önemli olmamaktadırlar.

«Gazetelere, haber ajansları neşriyatına ve belli aralıklarla yayınlanan diğer bütün basılmış eserlere mevkute» diyen Basın Kanûnunun 3. maddesi gereğince, Türkiye'de haber ajanslarının kurulması bakımından gazete çıkarılması için gereken hükümler uygulanmaktadır.32 Buna göre, haber ajansının kurulması, bir izne tâbi değildir, fakat adının, sahibinin ve varsa sorumlu müdürünün ad, uyruk, ve ikâmetgahlarını gösterir bir beyannamenin, çalışılacak yerin en büyük mülkiye âmirliğine verilmesi gerekmektedir.

Özel haber ajansları bakımından anlatılan yukarıdaki durum dışında, 1961 Anayasası ve 1486 sayılı kanunla getirilen değișiklikler gereğince, «devlet tarafindan kurulan veya devletten malî yardım alan haber ajanslarının tarafsızlığı esastır».33

Hukuki düzenleme açısından, Türk Haberler Ajansı ile Haber Ajansı Basın Kanûnu hükümlerine tâbidirler. Anadolu Ajansı ise,

(28) Hifzı Topuz, L'Information Internationale dans la presse turque, Paris; C.E.L.S.E, 1960 , s. $44-45$.

(29) Anadolu Ajansının 48. yılında çıkardığı broşür, Ankara 1969, Mehmet Ali Kişlalı, Özel ve Ulusal Ajanslar, BYYO'da 1971 yılında verilen konferans, teksir.

(30) Türk Haberler Ajansı Ankara Bürosundan alınan bilgiler.

(31) Haber Ajansı Ankara Bürosundan alınan bilgiler.

(32) Basin Kanûnu, madde 8-9.

(33) T.C. Resmî Gazete, 22 Eylül 1971, sayı 13964. 
devletin de payı bulunan bir anonim şirket olduğundan, ve devletten malî yardım aldığından, tarafsız olmak durumundadır.

Anadolu Ajansı, 1925 yılında kurulduğundan beri, devletin de ortak olduğu bir anonim şirkettir. Atatürk, şirket kurulurken, his. se senetlerinin $49 \%$ ni, Maliye Bakanlığına $51 \%$ ise basınla uğraşan çeşitli özel kişilere dağıtmıștır. Bugün aynı durum devam etmekle beraber, özel şahısların elinde bulunan senetlerin birkaç kişi dışında kimin elinde kaldığı pek bilinmemektedir. ${ }^{34}$

Anadolu Ajansının yanında özel ticari işletme olarak çalıștırılan Türk Haberler Ajansı da bir anonim şirkettir. 1950'de Kadri Kayabal tarafindan kurulan Türk Haberler Ajansı, 1958 yılında büyütülerek ortaklığa Tercüman, Milliyet ve Dünya gazeteleri ile Hayat Mecmuası eklenmiştir. Bugün için sermayenin $51 \%$ Kadri Kayabal'in, geri kalan $49 \%$ ise Tercüman, Milliyet, Dünya ve Ha. yat'a ait bulunmaktadır. ${ }^{35}$

1963 yılında gerçekleştirilen Haber Ajansı da Bir anonim şirket olarak çalıșmaktadır. Şirkette en büyük pay Hürriyet Matbaa: cılık A.S'nindir. Yalnız Hürriyet Gazetesine haber sattığından, giderlerini Hürriyet karşılamaktadır. ${ }^{36}$

Anadolu Ajansının yönetim merkezi Ankara'dadır. Türk Ha. berler Ajansı ile Haber Ajansları, Türk gazeteciliğinin merkezi durumunda olan İstanbul'da kurulduklarından, merkezleri halen orada bulunmaktadır.

Anadolu Ajansı, Adana, İzmir, İstanbul'da bürolar bulundurmakta, ${ }^{37}$ Türk Haberler Ajansı ise Ankara, İzmir, Eskișehir, Edirne, Samsun, Adana, Antalya, Diyarbakır, Erzurum'da büro çalıștırmaktadır. ${ }^{38}$ Haber Ajansının büroları ise Ankara, İzmir, Adana, Samsun, Diyarbakır ve Bursa'da bulunmaktadır. ${ }^{39}$

(34) Anadolu Ajansından alınan bilgiler.

Bugün için en çok elinde senet olanlar:

1 - Yakup Kadro Karaosmanoğlu halen Anadolu Ajansı Yönetim Kurulu Başkanı 75 pay

2 - Ahmet Ağaoğlu ve varisleri 75 pay

3 - Falih Rifki Atay ve varisleri 75 pay

4 - Bahadır Dülger ve varisleri 50 pay

5 - Ruşen Eşref Ünaydın ve varisleri 50 pay

(35) Türk Haberler Ajansından alınan bilgiler.

(36) Haber Ajansından alınan bilgiler.

(37) Anadolu Ajansindan alınan bilgiler.

(38) Türk Haberler Ajansı Ankara Bürosundan alınan bilgiler.

(39) Haber Ajansı Ankara Bürosundan alınan bilgiler. Son aylarda, sayılan bürolara Antalya ile Eskişehir büroları da eklenmiştir. 
Anadolu Ajansının Türkiye'nin her il ve ilçe merkezinde muhabiri olmasına karşılık, ${ }^{40}$ Türk Haberler Ajansının yukarıda sayılan bürolarının bulunduğu iller dişında her il ve ilçede tam zamanlı olarak çalıșan muhabirleri bulunmaktadır. ${ }^{41}$ Haber Ajansı'nin ise muhabirleri 430 il ve ilçede görevlidirler. ${ }^{42}$

Anadolu Ajansı'nın Bonn'da dış bürosu bulunmasına karşılık, Haber Ajansı ve Türk Haberler Ajansı dıș büro çalıștırmamaktadırlar. Haber Ajansının Reuters ile karşılıklı haber alıp verme antlaşması mevcuttur. ${ }^{44}$ Türk Haberler Ajansının United Press İnternational ve Reuters ile haber alma ve satma bakımindan resmi sözleşmesi olduğu gibi, iki yabancı ajansın çeșitli yurtdışı bürolarında, onlarla beraber çalıșan Türk Haberler Ajansı muhabirleri bulunmaktadir. ${ }^{45}$

Anadolu Ajansı ile Türk Haberler Ajansı günlük haber bültenleri içinde diş haberlere de yer vermektedir. Türk Haberler Ajansı dış kaynaklı haberlerini yukarıda anlatıldığı șekilde sağlarken, Anadolu Ajansı Atina Haber Ajansı, Tanyug (Yugoslav), Tass, ve D.P.A (Federal Almanya) ile karșılıklı haber alıșverișinde bulunmaktadir. Ayrica, Anadolu Ajansı Associated Press ile Agence France Presse'in dünya bültenine abone bulunmaktadır. ${ }^{46}$

Anadolu Ajansının abonelerine haber satışı bakımından uyguladığı abone ücreti gazetelerin tirajlarına göre değișmektedir. Anadolu Ajansının haber satıs hizmeti ya teleks makinesi kiralama yoluyla ya da teksir edilmiş bülten gönderme șeklindedir. Bugün için aylık teleks makinesi için alınan kira bedeli 350 T.L'dir. ${ }^{47}$

Türk Haberler Ajansı da Anadolu Ajansı gibi aynı șekilde çalıșmaktadır, fakat uyguladığı tarifeler Anadolu Ajansına oranla daha yüksektir. ${ }^{48}$ Haber Ajansı, karșılıklı antlașmaya göre haber satan bir ajans șeklinde kurulmuștur. 1970 yılı sonlarına kadar gazetelere abone karşılığında haber satarken, haber maliyetinin art-

(40) Anadolu Ajansından alınan bilgiler.

(41) Türk Haberler Ajansından alınan bilgiler.

(42) Haber Ajansından alınan bilgiler.

(43) Anadolu Ajansının daha önceleri Atina, Beyrut gibi șehirlerde dış büroları bulunmakla beraber., malî olanaklar yüzüinden kapatılmıș. tir.

(44) Haber Ajansı Ankara Bürosundan alınan bilgiler.

(45) Türk Haberler Ajansı Ankara Bürosundan alınan bilgiler.

(46) Anadolu Ajansindan alınan bilgiler.

(47) ibid.

(48) Türk Haberler Ajansından alınan bilgiler 
ması ile, haber satıș fiyatlarını yükseltince, gazeteler abonelerini bu ajanstan kesmişlerdir. Bugün yalnız Hürriyet Gazetesi ile TRT'ye haber satmaktadir. ${ }^{49}$

Anadolu Ajansının aboneleri arasında Türkiye'deki bütün gazeteler, büyükelçilikler, TRT, Basın Yayın Genel Müdürlüğü, SilâhIı Kuvvetler, iktisadi servisi bakımından ise ilgili Bakanlıklar ve bankalar ile özel teșebbüs bulunmaktadır.50 Türk Haberler Ajansı, haberlerini, Türkiye'de pek çok sayıda gazeteye, TRT'ye ve Basın ve Yayın Genel Müdürlügüüne satmaktadır. ${ }^{51}$

Anadolu Ajansı diğer iki ajanstan farklı olarak, Gölbaşında (Ankara) 9.10.1967'de kurulan telsiz istasyonu aracıliğı ile Türkiye haberlerini Fransızca olarak iki saat müddetle telsiz yayını ile dünyaya aynı anda vermektedir. Verilenler, Londra'dan Endonezya'ya, Moskova'da Kahireye kadar duyulabilmektedir. Ayrica, aynı istasyonla Batı Almanya radyolarına Türk işçileri için Türkiye haberleri verilmektedir. ${ }^{52}$

Türkiye'de gazeteciliğin hemen hemen bir buçuk yüzyıllık bir geçmişi olmasına rağmen, ajansçılık çok yenidir. Atatürk'ün duyduğu ihtiyaçla başlatılan ajansçılığın ancak 1960'lardan sonra gerçek hüviyeti anlaşılmıştır. Bugün için mevcut üç büyük ajans şu özellikleri tașımaktadırlar :

1 - Ajanslar hâlâ pratik, günlük ihtiyaçlar karşısında ortaya çıktıklarından, haberlerini gazeteler pek kullanmamaktadırlar. Yalnız büyük gazeteler bunların haberlerine rağbet etmektedirler.

2 - Olanakları ölçüsünde haber toplayıp yayabilmektedirler. Daha başka bir deyișle çabuk haber ulaştıramamaktadırlar.

3 - Verdikleri dıș haberleri bakımından yabancı ajanslara bağlı kalmaktadırlar; olayları yerinden izleyemememektedirler.

4 - Abone ücretleri bakımından, tirajlara göre ücret alındığından, oranlı bir durum söz konusu olamamaktadır.

5 - Ajanslar, küiçük gazeteler bakımından, bültenleri kullanıldığı ölçüde, haber maliyetini düșürmekte, hattâ muhabirlerin yerini almaktadırlar.

(49) Haber Ajansından alınan bilgiler.

(50) Anadolu Ajansından alınan bilgiler.

(51) Türk Haberler Ajansından alınan bilgiler.

(52) Anadolu Ajansı 48. yıl broşürüi, Ocak 1969. 